NBER WORKING PAPER SERIES

\title{
CAPITAL TAX INCIDENCE: FIRST IMPRESSIONS FROM THE TIME SERIES
}

\author{
Casey B. Mulligan
}

Working Paper 9374

http://www.nber.org/papers/w9374

\section{NATIONAL BUREAU OF ECONOMIC RESEARCH 1050 Massachusetts Avenue \\ Cambridge, MA 02138}

December 2002

I appreciate the comments of David Cutler and Marty Feldstein, and the research assistance of Fabian Lange and Justin Marion. This research was made possible by financial support from the University of Chicago's George Stigler Center for the Study of the Economy and the State. The views expressed herein are those of the authors and not necessarily those of the National Bureau of Economic Research.

(C) 2002 by Casey B. Mulligan. All rights reserved. Short sections of text, not to exceed two paragraphs, may be quoted without explicit permission provided that full credit, including $(\mathcal{C}$ notice, is given to the source. 
Capital Tax Incidence: First Impressions from the Time Series

Casey B. Mulligan

NBER Working Paper No. 9374

December 2002

JEL No. H22, E22, H30

\begin{abstract}
Aggregate time series data are used to calculate the incidence of capital taxes. Part of the analysis is borrowed from the literature on sales tax incidence, comparing pre-tax interest rates with tax rates. The other part compares tax rates with after-tax interest rates, which are measured separately and independently from pre-tax interest rates. I find a positive correlation between capital tax rates and pre-tax interest rates, and little correlation between after-tax interest rates and tax rates, but both of these findings seem to derive in part from the effect of the business cycle on tax rate measures, as opposed to a shifting of capital taxes. The empirical findings are consistent with significant capital tax shifting in the long run, little shifting in the short run, and clearly rule out over-shifting.
\end{abstract}

\author{
Casey B. Mulligan \\ Department of Economics \\ University of Chicago \\ 1126 East $59^{\text {th }}$ Street \\ Chicago, IL 60637 \\ and NBER \\ c-mulligan@uchicago.edu
}




\section{Introduction}

Who bears the burden of capital income taxes? This is an important question because capital income tax rates have increased so much over time, and vary a lot across countries. The U.S., for example, introduced federal corporate taxation in 1909, and rates reached as high as $52 \%$ during the 1950's (Cummins et al 1994), and now stand at 35\%. Europeans have been cutting their rates - for example, the 20 percentage point cuts in Germany and Ireland between 1995 and 2001 (American Council for Capital Formation 2001, citing PricewaterhouseCoopers) - to the point where most Western European countries have lower rates than does the U.S. Estimates of capital tax incidence may also tell us something about the market for capital, and capital's place in a full model of the economy.

One approach to calculating tax incidence is to build a general equilibrium model of the supply and demand for capital, choose numerical values for its parameters, and then simulate preand post-tax interest rates under various policy options. Harberger's 1962 paper is a famous example of this approach. The approach of my paper is to use measurements of pre- and post-tax interest rates, and compare their evolution over time to the time pattern of tax rates. A few previous studies have used a related approach to study the incidence of excise taxes (eg., Due 1954, Evans et al 1999 and the papers referenced therein), payroll taxes (Mitrusi and Poterba 2000), and retail sales taxes (Haig and Shoup 1934, Poterba 1986, Besley and Rosen 1999) - namely to look at correlations between a price series and tax rates. Half of my analysis is quite analogous with theirs, although one difference is that I separately and independently construct measures of pre-tax and post-tax interest rates, and thereby provide two independent estimates of the incidence of capital income taxes.

To be more specific, I consider time series regressions of the log pre-tax interest rate $r$ on the $\log$ of the after-tax share:

$$
\ln r_{t}=\alpha-\beta \ln \left(1-\tau_{t}\right)+\varepsilon_{t}
$$


where $\tau_{t}$ is the year $t$ capital tax rate, $\varepsilon_{t}$ captures other determinants of rental rates, and $\beta$ is the fraction of the capital tax passed on, rather than being paid by savers. Equation (1) has a log-linear functional form, which is convenient since it is readily decomposed into "anticipated" and "unanticipated" components and, since the after-tax interest rate is $r_{t}\left(1-\tau_{t}\right)$, it implies that the fraction of the capital tax paid by capital is $(1-\beta)$. Capital bears all of the burden when $\beta=1$ and none of the burden when $\beta=0$. The capital tax burden is "over-shifted" when $\beta>1$.

Substituting equation (1) into the definition of the after-tax interest rate, we have equation (2):

$$
\ln \left[r_{t}\left(1-\tau_{t}\right)\right]=\alpha+(1-\beta) \ln \left(1-\tau_{t}\right)+\varepsilon_{t}
$$

which says that we can also infer $\beta$ using measures of after-tax returns. My paper uses consumption growth and various financial returns to make these inferences.

The empirical approach has the advantage that it does not require a numerical model of the entire economy, or a struggle with interpreting the results of such a model when it is known to have some important inconsistencies with observation. But the empirical approach has the disadvantage that tax rate fluctuations over time may be a reaction to, or just coincident with, other economic fluctuations (in terms of equations (1) and (2), $\tau$ is correlated with $\varepsilon$ ), so that it is difficult calculate the counterfactual time series that would have been realized under a different capital tax policy. Another disadvantage is that it is hard to determine when information about capital tax changes began to be included in investment decisions.

Section II presents my interest and tax rate data. Section III looks at medium-term fluctuations of capital taxes and rental rates. Section IV displays regressions of various pre-tax and post-tax interest rate measures on various capital tax rate measures.

\section{Measures of Pre- and Post-Tax Returns on Capital}

\section{II.A. Capital Returns as Measured in the National Accounts}

One measure of the pre-tax interest rate is capital income net of depreciation per dollar of 
capital in place at the beginning of the year. Capital is measured as proportional to the BEA's (2000) fixed assets valued at current cost, and is aggregated for private residential and nonresidential sectors. ${ }^{1}$ Note that the capital measured is employed domestically (including foreign-owned capital), includes owner-occupied housing, excludes consumer durables, and excludes the government sector. Current cost capital is not the same as book value, because the former aggregates real investment flows, and the latter aggregates investment expenditure flows. Capital income is measured accordingly, in three steps. First, income accruing to agents with their factors domestically and privately employed is calculated by subtracting net government product ${ }^{2}$ and net factor income from abroad from national income. Second, this income is multiplied by one minus labor's share of nonproprietors' private national income, in order to obtain an estimate of the income pre-direct-taxes going to domestically employed capital. ${ }^{3}$ Third, property income tax revenue is added back into capital income, as suggested by Feldstein, Dicks-Mireaux, and Poterba (1983), the result is a capital rental rate before all taxes, and perhaps the better proxy for the marginal product of capital. Figure 1 displays this series as a dash-dot line. The solid line is a calculation of the pre-tax rental rate, based on the assumption (required in order to have a series prior to 1929) that property taxes are zero, and is therefore called the "pre-direct-tax" rental rate.

${ }^{1}$ Data sources are detail in the Appendix.

${ }^{2}$ Government net product is equal to the compensation of government employees, because, as explained by Parker et al (1995, p. 36), the national accounts assume that government assets (other than those used by government enterprises selling their output in the marketplace) yield no services in production beyond their depreciation.

${ }^{3}$ These two steps implicitly assume that capital and labor income accrue in the same shares in three sectors - the nonproprietary sector, the proprietary sector, and the foreign sector. My formula for pre-direct-tax private sector capital income is $\left(N I-Y_{g}-N F I\right)\left[1-W_{p} /\left(N I-W_{g}-Y_{s}\right)\right]$, where $Y_{s}$ is proprietors' income, $N I$ is national income, $N F I$ is net factor income from abroad, $W_{p}$ is the private employee compensation of domestic residents, and $W_{g}$ is the labor compensation of domestic government employees. 


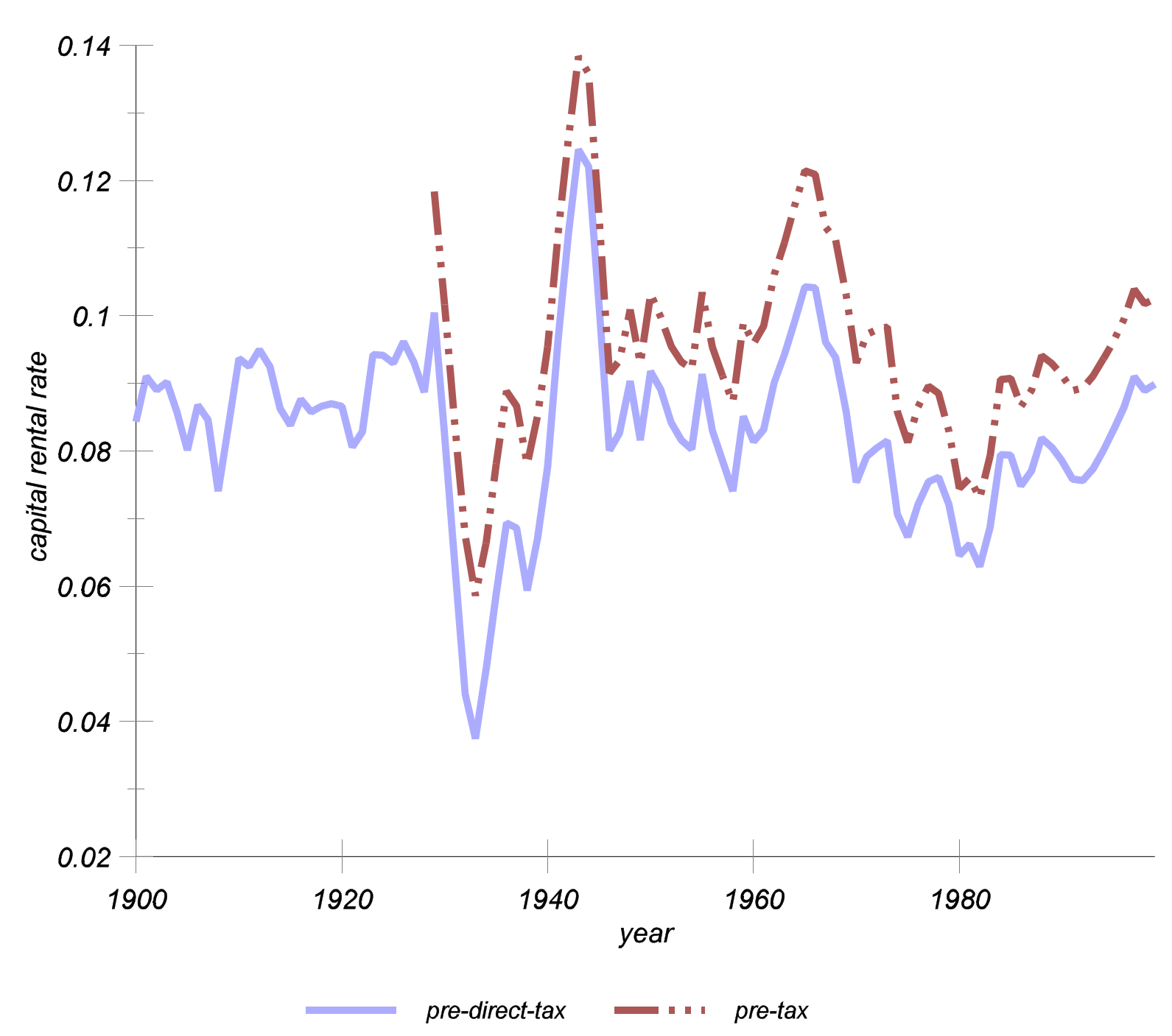

Figure 1 Capital Rental Rates

\section{II.B. Financial Returns}

Financial asset returns may also be related to capital returns, although it is hard to say for sure whether, for example, the commercial paper return is tied to the pre-tax, or the post-tax capital rental rate. Personal capital income taxes may drive a wedge between consumers' intertemporal marginal rate of substitution and the commercial paper return, unless commercial paper were not held by agents paying personal income taxes. If a financial asset is held by agents liable for personal income taxes, then we expect some passing on of the personal capital income tax via a higher return on that financial asset.

Corporate income taxes should reduce the return on corporate stocks, to the extent that those 
taxes are less than fully passed on via a higher capital rental rate. Stock returns thereby provide a cross-check on our interpretation of the rental rate - tax rate correlation. If higher corporate tax rates are associated with both higher rental rates and higher stock returns, then maybe tax policy tends to be procyclical, rather than (or in addition to) higher rental rates' reflecting the passing on of tax rates.

Because of the debt-equity puzzle, it hard to say for sure how bond returns would be affected by corporate taxation. On one hand, if consumers are willingly holding both stocks and bonds, and personal income tax rules are held constant, higher corporate income taxes should reduce stock and bond returns by roughly the same amount. ${ }^{4}$ One the other hand, if corporations are willingly issuing both debt and equity, then a high corporate tax rate should increase the return on bonds (whose interest payments are deductible from the corporate income tax) relative to the return on stocks.

I argue elsewhere (Mulligan 2002) that the consumption-asset-pricing and production-assetpricing literature suggest that financial asset returns are noisier measures of the return on capital (pre- or post-tax) than capital's rental rate. This noise may only widen confidence intervals on tax incidence estimates derived from financial asset returns or, to the extent that departures between financial asset and capital returns are correlated with capital's return or with capital tax rates, the incidence estimates may be biased.

\section{II.C. Capital Tax Rates}

There are many kinds of capital, and many forms of capital taxation. One approach might be to explicitly model this complexity, but $\mathrm{we}^{5}$ follow Griliches and Jorgenson (1966, p. 58), Feldstein, Dicks-Mireaux, and Poterba (1983), Lucas (1990), and Mendoza et al (1994) and attempt to construct annual measures of the rate $\tau_{t}$ of taxation of a representative piece of capital's date $t$ income. More specifically, we use the following formula:

${ }^{4}$ Feldstein and Summers (1978, p. 162) take this approach.

${ }^{5}$ The estimates in this section were made possible by ongoing research with Justin G. Marion. Some of those results are reported in Mulligan and Marion (2000). 


$$
\begin{aligned}
& \qquad \tau_{t}=\frac{T_{t}+P_{t+1}}{R_{t}+P_{t}} \\
& T_{t} \equiv \text { (corporate inc tax revenue) } \\
& +(\text { estimated personal capital inc tax revenue) } \\
& + \text { (property tax revenue) } \\
& \text { (estimated personal capital inc tax revenue) } \equiv \\
& \text { (nonlabor inc share of AGI) (total IIT revenue) }
\end{aligned}
$$

where $R_{t}$ is date $t$ aggregate capital income before direct taxes and after indirect taxes, and $P_{t}$ is property tax revenue received by the government in year $t$. These are similar to Mendoza et al's measures, with four exceptions (i) our definition of capital income is slightly different, (ii) we added property taxes back into the aggregate capital income (see the denominator, and also Feldstein, Dicks-Mireaux, and Poterba 1983), and (iii) we count tax revenue according to the tax year. ${ }^{6}$ On point (iii), we have used IRS records to measure personal and corporate tax liabilities by tax year. On point (iv), when we have data on aggregate property tax revenue (1929-), we assume that property tax liabilities accrue in the year prior to their arrival at the treasury, as indicated in the formula above.

Figure 2 displays my measure of capital income tax rates, decomposed into the corporate, personal, and property tax components. We see how the corporate income tax accounts for most of the tax rate fluctuations, with the exception of the 1930's when corporate and personal income tax revenues were few and property tax revenues were substantial relative to capital income. ${ }^{7}$

${ }^{6}$ Lucas (1990) uses a similar method to measure the capital tax rate for $1985(0.36)$. Mendoza et al (1994) and Lucas (1990) apparently count revenue according to the year it arrives in the Treasury and therefore in the government budget. For example, a personal income tax payment made April 15, 1985 for the 1984 tax year would count as 1984 in my calculations and as 1985 in the Mendoza et al/Lucas calculations.

${ }^{7}$ We conjecture that property tax assessors did not adjust the dollar value of their assessment during the 1930 's, when the overall price level and dollar incomes were falling, which is why aggregate property tax revenue was pretty stable in dollar terms and such a large fraction of aggregate capital income. 


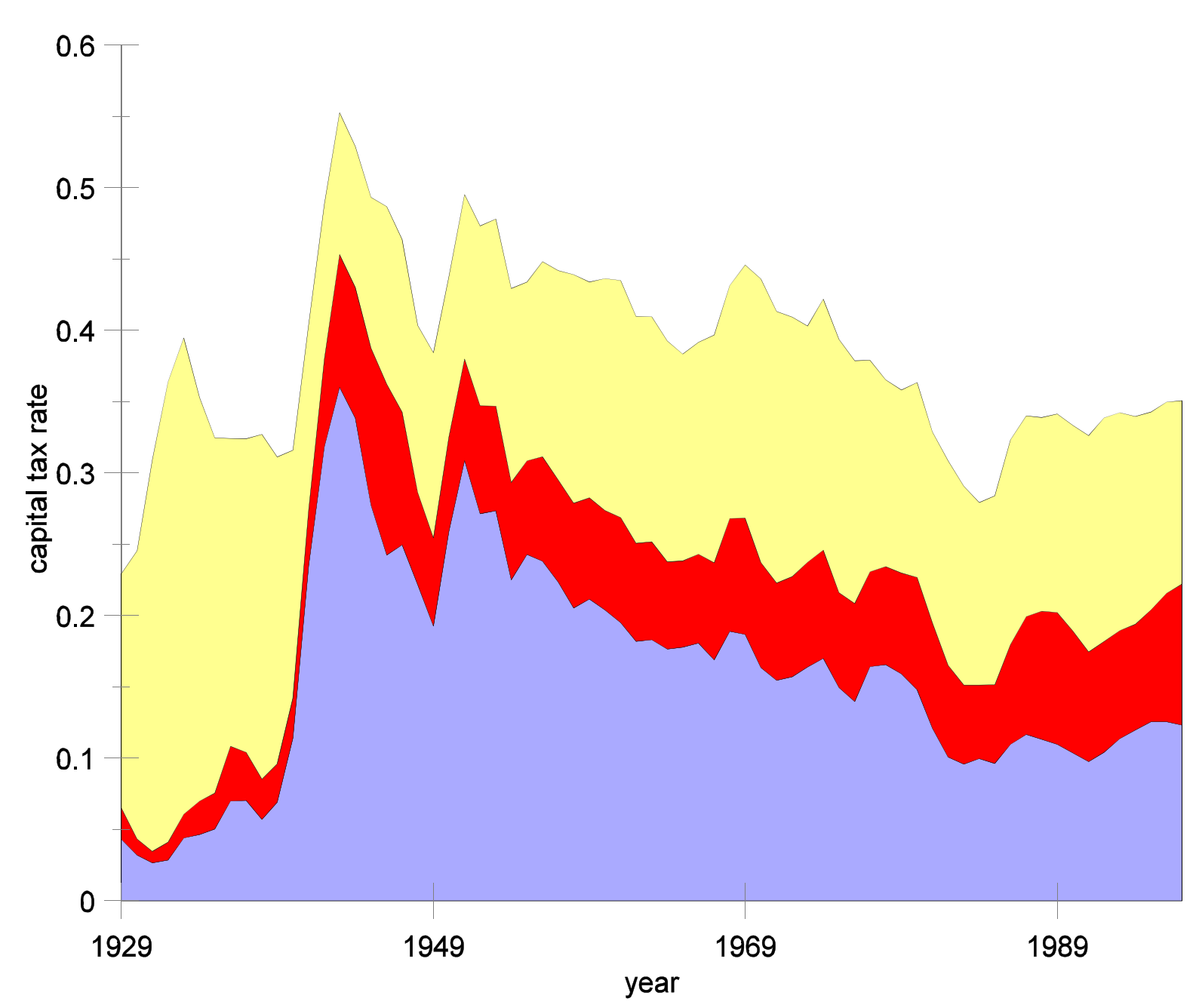

Property

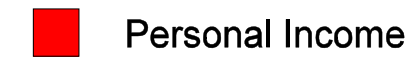

Corporate Income

Figure 2 Capital Income Tax Revenues by Major Type, 1929-97 (as a share of aggregate capital income, before direct and property tax)

Since the changes in the after-tax rental rate that are associated with measured tax changes are an important ingredient in my analysis, it is worth understanding some of the history of those tax changes. The major ones are associated with real, although sometimes passive, changes in public policy. For example, the higher levels since 1940 derive from the well known increase in government revenue's share of GDP, part of which was financed with the introduction and growth of corporate and personal income taxation. The reduction at the end of the war derives from reductions in corporate and personal income tax rates, and probably in part from legislative adjustments of nominal tax code to the higher postwar price level. Federal corporate income tax rates increased from 38 to 52 percent 1949-52, contributing to the rapid increase in my corporate 
measure during those years. Federal corporate rates were temporarily increased in 1968 and 1969 , which presumably contributes to Figure 2's higher measured rate for 1968 and 1969. Feldstein and Summers (1979) and Auerbach (1983) explain how high inflation generated higher corporate income tax revenues in the 1970 's relative to the 1980 's, and how this increase is indeed a tax on the returns to investment. Auerbach (1983, p.455), and Cummins, Hassett, and Hubbard (1994, p. 6) explain how depreciation allowances were liberalized in 1981. Cummins, Hassett, and Hubbard also explain how the federal corporate income tax's contribution to the effective tax rate on equipment and structures increased 1983-87, despite 1986 reductions in the corporate income tax rate, because of reduced depreciation allowances and investment credits.

\section{II.D. Potential Biases in Measured Tax Rates}

There are a number of reasons to expect that the anticipated capital tax rate might be measured with error, and that those errors would affect incidence estimates. One important issue in this regard is whether the rate of capital taxation is anticipated at the time that investment occurs and consumption is foregone. The typical legislative calendar is informative in this regard, since tax laws (ie, schedules relating capital income of various types to tax liabilities) are usually debated and passed prior to the tax year during which they are in force, we can reasonably suppose that investors have a good idea of the one-year-ahead relation between capital income and capital income tax liability. If capital income taxes were literally proportional, then this would imply that marginal tax rates are also well anticipated one year ahead. Marginal corporate and personal income tax rates are, in the relevant range, fairly constant with income.

Related is the question of whether average and marginal capital income tax rates are the same. Again the proportionality of tax rules is relevant. Also relevant is whether old and new capital are treated symmetrically. For example, we could imagine a policy that heavily taxes old capital, thereby generating substantial revenue (measured as a ratio to the capital stock at the time of the levy), and the appearance of a high rate of capital taxation, but did not discourage investment in the year prior to the levy.

These and other departures between the average tax rate (as measured) and the anticipated marginal rate are sources of measurement error of the tax rate. If this measurement error were uncorrelated with the pre-tax rental rate $r$, then we expect incidence estimates to suffer from the usual regression bias if those estimates are calculated by a least squares regression of $r$ on the 
measured after-tax share. If the gap between marginal and average rates were correlated with $r$, then the bias could be in any direction depending on the sign and magnitude of the correlation. It seems that such departures might be procyclical, and hence positively correlated with $r$, because tax policy makers may attempt to "lean against the wind" and otherwise induce average tax rates to be more procyclical than anticipated marginal rates. ${ }^{8}$ If so, the bias in a regression of $r$ on the measured aftertax share could be downward, rather than upward as with the usual regression bias cited above, because tax rates are overestimated (underestimated) during booms (recessions).

For example, investment tax credits (ITC) create a difference between average and marginal rates, and one that we can expect to be positively correlated with rental rates. One reason is simply that ITCs have been subtracted from other capital tax liabilities during the computation of capital tax revenue. A large ITC during year $t$ relative to year $t-1$ may discourage year $t-1$ investment (and thereby encourage year $t$-1 consumption) while at the same time reduce average tax rates in year $t$.

Another bias may derive from the composition of capital income taxes and the differential cyclicality of their tax bases. ${ }^{9}$ Suppose for the sake of illustration that property tax are zero, and that all capital income falls either under the corporate tax or the personal tax but not both. Then my capital tax rate measure is the weighted average of the corporate and personal tax rates $\tau_{t}^{c}, \tau_{t}^{p}$, respectively:

$$
\begin{gathered}
\tau_{t}=\theta_{t} \tau_{t}^{c}+\left(1-\theta_{t}\right) \tau_{t}^{p} \\
\theta_{t} \equiv \frac{R_{t}^{c}}{R_{t}^{c}+R_{t}^{p}}
\end{gathered}
$$

where the $R$ 's are the personal and corporate components of capital income. The formula above shows that, if the composition of capital income is cyclical, then the business cycle may cause

${ }^{8}$ For example, the famous Kennedy tax cuts were said to be designed to stimulate the economy. Perhaps similar motives were relevant for the Reagan tax cut. World War II is an example where a third factor (the war) led to both economic expansion and higher capital income tax rates.

${ }^{9}$ I owe this point to Marty Feldstein. 
fluctuations in my measured tax rate even when the personal and corporate rates are constant. In particular, if $\tau_{t}^{c}>\tau_{t}^{p}$ and the corporate tax base is the more cyclical, then my tax rate measure will be procyclical even when personal and corporate rates are not. One way to deal with this bias is to look at tax rate measures based on statutory provisions rather than measures based on revenues.

\section{II.E. Expected vs. Realized Returns}

When modeling the supply and demand for capital, it is the expected return (pre-tax and post-tax) and the expected rate of taxation that are most interesting, and we will want to calculate the degree to which expected capital taxation raises expected pre-tax returns rather than lowering expected after-tax returns. This degree is potentially different from the degree to which unexpected capital taxation is associated with an unexpected increase in pre-tax returns.

"Expected" returns and tax rates are calculated using a VAR model, which includes log pretax rental rate, $\log$ (1-capital tax rate), nominal paper and bond yields, inflation, stock returns, the unemployment rate, and consumption growth. For some of the specifications, bond yields and inflation are excluded, in order to obtain separate estimates of expected returns pre- and post tax.

\section{II.F. Independent Measures of the After-tax Return}

Of course, we could combine the measured tax rates with measured pre-tax returns to obtain a measure of after-tax returns, but this would not add any new information. But the Fisherian theory of savings, as embodied in many modern macroeconomic models, implies that expected consumption growth is related to the expected after-tax return:

$$
E_{t-1}\left[\ln \frac{c_{t}}{c_{t-1}}\right]=\sigma E_{t-1}\left[\left(1-\tau_{t}\right) r_{t}\right]-\sigma \rho_{t-1}
$$

where $c_{t}$ denotes aggregate consumption in year $t, \sigma>0$ is the constant intertemporal elasticity of substitution, $E_{t-1}(\cdot)$ denotes expectations as of year $t-1$, and the parameter $\rho$ allows for changes over time of intertemporal preferences, (nontax) capital market distortions, or specification errors. So we can regress expected consumption growth on the capital tax variables, and the coefficient on the capital tax variables, scaled up by $\sigma$, is an estimate of the effect of the tax variables on the after-tax 
return.

\section{Medium-Term Correlations}

I begin by dividing the $20^{\text {th }}$ Century into five-year intervals $1901-05, \ldots$, and for each interval calculate the average $\ln r_{t}$ and the average $\ln \left(1-\tau_{t}\right)$. These are scatter-plotted in Figure 3, with the war and pre-war data shown as red squares, and the post-war data as black ovals. In order to have observations prior to 1929 , I assume for the purpose of preparing the graph that property taxes were zero in every year, and splice the BEA capital stock series with Kendrick's (1961). The analysis below will not require this assumption, and I strongly suspect that the conclusion to be drawn from the Figure are insensitive to this assumption.

The Figure shows an overall negative relation between rental rates and the after-tax share; the regression slope is -0.27 . In terms of equation (1), this could be interpreted as a finding that $27 \%$ of the capital tax is passed on in the form of higher rental rates $(\beta=0.27)$, although closer inspection of the graph suggests that 0.27 is by no means the best estimate of capital tax incidence. Namely, the extreme observations are from the Great Depression and WWII. It is likely that Depression rental rates would have been low even if there had been capital taxation. It is also likely that WWII separately caused high rental rates and the introduction of capital taxation, rather than one causing the other.

Prior to the Depression rental rates were quite average by postwar standards, even though there was hardly any capital taxation. Hence, comparing the pre-1930 period to the post-war period suggests that capital bears all of the burden of capital income taxes! Making comparisons over such a long time period is dangerous, and the data I have is probably inappropriate for such a comparison, but hopefully future research can produce improved estimates of rental rates pre-1929.

Table 1 displays some other interest rate measures that permit cross-checking of this interpretation. If capital bears all of the burden of the corporate income tax, then consumption growth and stock returns should be lower post-war with the amount of the reduction commensurate with the increased rate of capital taxation. Bond returns may be higher, depending on how we model the debt-equity puzzle. In fact, we see little long-term evidence that corporate taxes are passed on 


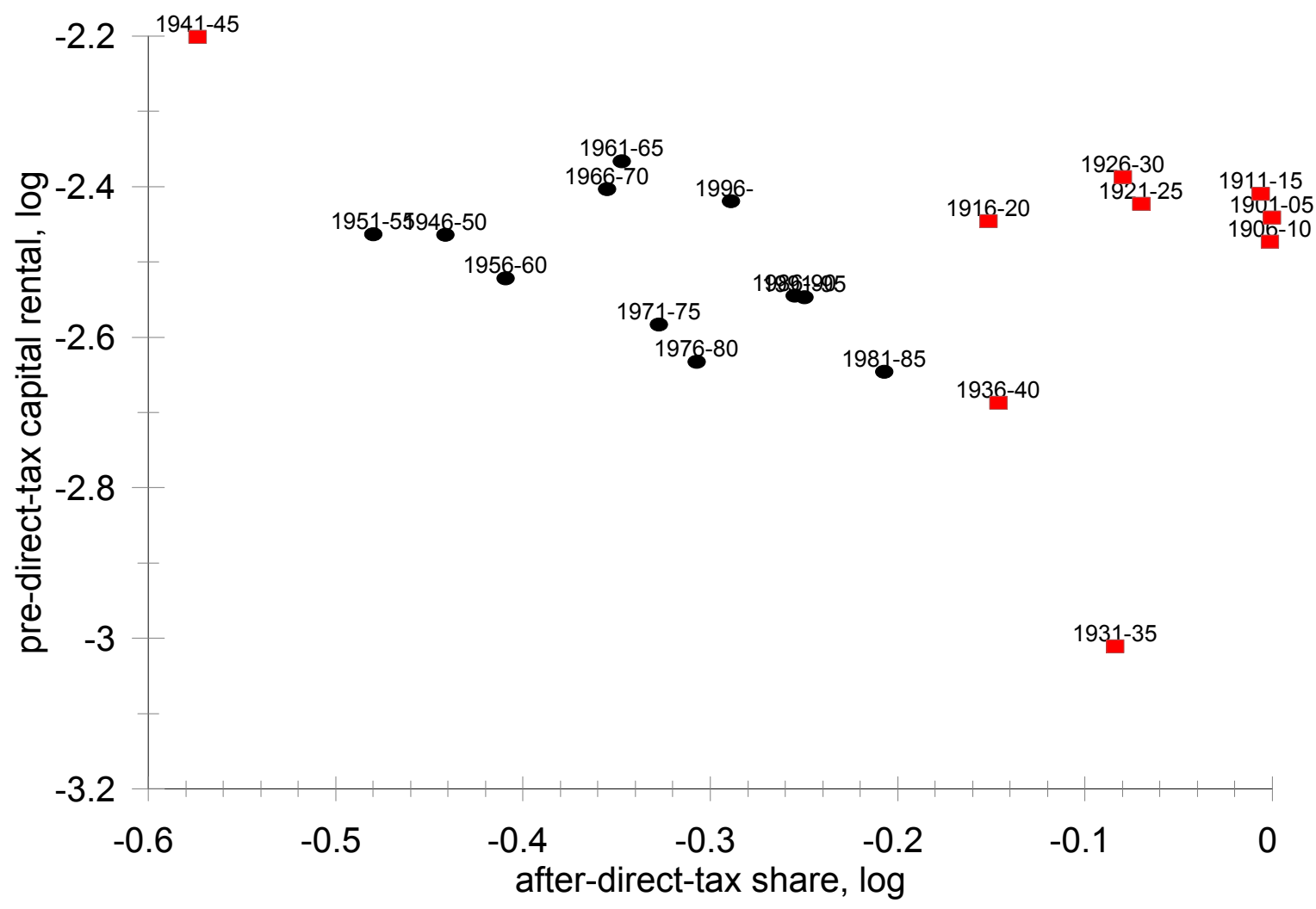

Figure 3 Capital Tax and Rental Rates 
to savers, because consumption growth and real stock returns have risen slightly. ${ }^{10}$ Hence, long term comparisons with the saver-side data suggest that capital bears none of the burden of the corporate tax, while the rental rate data suggests that it bears it all!

Table 1: Long Run Trends for the Interest Rate Indicators

\begin{tabular}{lll} 
& $1901-29$ average & $1947-96$ average \\
\hline pre-direct-tax rental & 0.088 & 0.082 \\
consumption growth & 0.018 & 0.020 \\
real stock return & 0.078 & 0.085 \\
real paper return & 0.028 & 0.017 \\
\hline
\end{tabular}

Another approach is to discard the pre 1930 data because of its questionable quality, and add the unemployment rate as a control for the procyclicality of tax policy. Doing so yields a coefficient of -0.69 on $\ln \left(1-\tau_{t}\right)$; capital appears to bear about $1 / 3$ of capital income taxes.

Within the postwar period (see the black ovals in Figure 3), we see a significant negative correlation between rental rates and the after-tax share; the regression slope is $-0.53 .{ }^{11}$ Hence, our first impression from the postwar period is that capital bears slightly less than half of the burden of capital taxes. Adding the unemployment rate produces a $\ln \left(1-\tau_{t}\right)$ coefficient of +0.41 . Consumption growth and financial return series also suggest that capital bears at least some of the burden, but also that the procyclicality (across these post-war 5-year intervals) of capital tax policy is limited, because stock and real paper returns are negatively correlated with the capital tax rate (excluding the personal tax component). Interestingly, real paper returns are negatively correlated with the personal component of capital taxes (even when the other two components are held constant). Consumption growth is positively correlated with the personal component of capital taxes, and

\footnotetext{
${ }^{10}$ Real stock returns may be significantly lower after personal taxes, depending on the magnitude of the post-war tax we applied to these returns. Also note that stock return estimates necessarily have pretty large standard errors.

${ }^{11}$ The slope is -0.54 if we use the dash-dot series shown in Figure 1, which account for property taxes.
} 
uncorrelated with the others, which may suggest that capital is not bearing much of the burden, or that capital taxation tends to be higher in the high return periods.

\section{Correlations Found in the Annual Time Series}

Higher tax wedges should be associated with higher pretax returns and lower after-tax returns. Table 2 explores these associations in the annual time series data. Each column reports results from a regression of $\ln$ (pre-tax capital rental rate) on $\ln (1$-capital tax rate), where the latter takes on its actual value, its value as forecast from prior year data, ${ }^{12}$ or the residual from that forecast. Since the after-tax rental rate is (1-capital tax rate) times the pre-tax rental, the regression coefficient should be negative and its magnitude can be interpreted as the fraction of the capital tax passed on to labor (ie, $\beta$ from equation 1).

${ }^{12}$ The coefficients for creating the "forecast" use the entire sample period 1947-96. 
Table 2: Pre-tax Rental Rates and Capital Taxes, 1947-96

(dependent variable is log (pre-tax capital rental rate))

specification:

(1)

(2)

(3)

(4)

(5)

(6)

(7)

independent variables

$\ln (1-$ capital tax rate), actual $\quad-0.51$

$(0.17)$

0.31

$-0.73$

$(0.20)$

$(0.25)$

$\ln$ (1-capital tax rate), forecast

$\begin{array}{ll}-0.65 & -0.57\end{array}$

0.22

$(0.17) \quad(0.27)$

$(0.23)$

$\ln (1$-capital tax rate), residual

$\begin{array}{ll}0.58 & 0.58\end{array}$

0.58

(0.48) (0.49)

$(0.40)$

$\ln (1-\mathrm{MTR})$, actual

unemployment rate, lagged

0.57

actual

unemployment rate, forecast

$-6.76 \quad-6.36$

(1.20) (1.31)

\begin{tabular}{llllllll}
\hline adj-R ${ }^{2}$ & .14 & .22 & .21 & .48 & .47 & .18 & .15 \\
\hline
\end{tabular}

Notes: (1) A constant term is included in all specifications

(2) Variables used to forecast are the promised (as of the prior year) nominal yield on commercial paper, the gap between yields on BAA and AAA bonds, and lagged: consumption growth, stock return, $\ln$ (1-capital tax rate), unemployment rate, inflation, and $\ln$ (rental rate).

(3) MTR is the Cummins et al marginal corporate tax rate measure.

(4) Columns (5) and (6) include only the years 1954-89.

The first column displays a coefficient of -0.51 . This suggests that about half of the capital tax is borne by capital, although we suspect that the coefficient is biased down due to other reasons for the cyclicality of the tax rate. For example, it may be that policy-makers anticipate rental rate fluctuations, and "lean against the wind" by taxing capital heavily when the rental rate is high. Another possibility is that I mismeasure the tax incentives to accumulate capital so that, for example, my measured tax rate is more cyclical than the true tax rate. These two hypotheses can be distinguished in part by separating the anticipated and unanticipated components of the tax variable. Column (2) shows a coefficient of -0.65 on the "anticipated" component, and a coefficient on the unanticipated component that is not statistically different from zero. Hence, cyclical measurement biases may not be important, at least if they are present in the unanticipated component. Column 
(3) suggests that column (2)'s result may not derive from cyclical tax policy as captured by the lagged unemployment rate. However, columns (4) and (5) suggest that the unemployment rate forecast predicts the rental rate and, conditional on it, high tax rates are not associated with higher rental rates.

Columns (6) and (7) tell us something about the effects of deviations of my measured tax rate from the statutory tax rates. "MTR" is the marginal tax rate derived from the statutory tax prices calculated by Cummins et al (1994, Table 1) for manufacturing equipment and structures (and averaged across asset types weighting by the net stock of those assets). Column (6) replicates column (1) for the years 1954-89 when the Cummins et al measure is available, and reports a coefficient on the tax share term of -0.73 . The coefficient is reduced in magnitude, but is still significant, when MTR replaces my tax rate measure. ${ }^{13}$

Table 3 examines the indicators of after-tax returns. The first two specifications show that consumption growth between years $t-1$ and $t$ is not correlated with capital taxation in year $t$. This might occur because capital does not bear any of the burden of the capital tax, or that capital taxation in fact reduces consumption growth but that measured capital tax rates happen to respond to other cyclical variables. Column (3) checks this by adding the unemployment rate forecast to the regression, and we see how the forecast predicts consumption growth, and conditional on the forecast, there may be a positive correlation between the tax share forecast and consumption growth. The standard error is fairly large, but the 0.08 point estimate is consistent with no shifting. ${ }^{14}$ Column (4) is also consistent with little or no shifting, at least if tax rates were persistent over time in addition to responding to cyclical variables, because it shows that consumption growth is less after a period of high personal capital taxation. Columns (5)-(8) suggest that lagged tax rates may predict nondurables and services growth somewhat better than they predict nondurables growth. ${ }^{15}$

${ }^{13}$ MTR and my tax rate measure are correlated 0.92 .

${ }^{14}$ Holding $r$ constant (ie, no shifting), effect of $\ln (1-\tau)$ on expected consumption growth is $-\sigma r(1-\tau)$. Mulligan (2002) estimates $\sigma=1$ with these data, and $r(1-\tau)$ is about 0.08 , so the expected coefficient on $\ln (1-\tau)$ is 0.08 when there is no shifting.

${ }^{15}$ The results are similar if my tax rate measure is replaced by Cummins et al's MTR, and the sample is restricted to the available years 1954-89. 
Table 3: Consumption Growth and Capital Taxes, 1947-96

\section{specification:}

consumption measure:

independent variables

\begin{tabular}{|c|c|c|c|}
\hline $\ln (1$-capital tax rate), actual & $\begin{array}{l}-0.01 \\
(0.03)\end{array}$ & & \\
\hline ln (1-capital tax rate), forecast & & $\begin{array}{l}-0.01 \\
(0.17)\end{array}$ & $\begin{array}{c}0.08 \\
(0.04)\end{array}$ \\
\hline In (1-capital tax rate), forecast residual & & $\begin{array}{l}-0.05 \\
(0.08)\end{array}$ & $\begin{array}{l}-0.05 \\
(0.08)\end{array}$ \\
\hline
\end{tabular}

Pers. portion of capital tax rate, lagged

Corp. portion of capital tax rate, lagged

Property portion of capital tax rate, lagged

unemployment rate, forecast
(2)

(3)

(4)

(5)

(6)

(7)

(8)

nondurable expenditure only nondurables and service expenditure

\begin{tabular}{lllllllll} 
& \multicolumn{3}{c}{$(0.26)$} & & $(0.21)$ & \\
\hline adj-R $R^{2}$ & -.02 & -.03 & .07 & .00 & .00 & -.02 & .00 & .19 \\
\hline
\end{tabular}

Notes: (1) Dependent variable is consumption growth. A constant term is included in all specifications

(2) Variables used to forecast are the promised (as of the prior year) nominal yield on commercial paper, the gap between yields on BAA and AAA bonds, and lagged: consumption growth, stock return, ln (1-capital tax rate), unemployment rate, inflation, and $\ln$ (rental rate). 
Table 4's first two columns suggest that commercial paper returns tend to be lower when capital tax rates are higher, and that this relation derives from the forecastable component of the tax rate. One interpretation is that it is part of the absorbing of the capital tax by savers, although in theory lower bond returns would occur only if the capital taxation was on property or the corporation, because bond interest is taxable by the personal income tax. Column (3) suggests that this interpretation may only be partly correct: higher corporate rates are associated with lower paper returns, but so are higher personal tax rates. A fairly similar pattern is seen for stock returns, as shown in columns (4) and (5). Higher personal tax rates, and perhaps also higher property tax rates, are associated with lower stock returns. 
Table 4: Financial Asset Returns and Capital Taxes, 1947-96

$$
\text { specification: }
$$

dependent variable:

independent variables

$\ln (1$-capital tax rate), actual

$\ln (1$-capital tax rate), forecast

$\ln$ (1-capital tax rate), forecast residual

Pers. portion of capital tax rate, actual

Corp. portion of capital tax rate, actual

Property portion of capital tax rate, actual paper return
(2)

0.24

$(0.04)$
(3)

stock stock

\begin{tabular}{|c|c|c|c|c|c|}
\hline $\begin{array}{l}\text { dependent variable: } \\
\text { independent variables }\end{array}$ & $\begin{array}{l}\text { paper } \\
\text { return }\end{array}$ & $\begin{array}{l}\text { paper } \\
\text { return }\end{array}$ & $\begin{array}{l}\text { paper } \\
\text { return }\end{array}$ & $\begin{array}{l}\text { stock } \\
\text { return }\end{array}$ & $\begin{array}{l}\text { stock } \\
\text { return }\end{array}$ \\
\hline $\ln$ (1-capital tax rate), actual & $\begin{array}{c}0.24 \\
(0.04)\end{array}$ & & & & \\
\hline $\ln (1$-capital tax rate), forecast & & $\begin{array}{c}0.25 \\
(0.04)\end{array}$ & & $\begin{array}{c}0.12 \\
(0.24)\end{array}$ & \\
\hline $\ln (1$-capital tax rate), forecast residual & & $\begin{array}{c}0.19 \\
(0.11)\end{array}$ & & $\begin{array}{c}0.03 \\
(0.69)\end{array}$ & \\
\hline Pers. portion of capital tax rate, actual & & & $\begin{array}{l}-0.83 \\
(0.33)\end{array}$ & & $\begin{array}{l}-2.71 \\
(2.16)\end{array}$ \\
\hline Corp. portion of capital tax rate, actual & & & $\begin{array}{l}-0.41 \\
(0.06)\end{array}$ & & $\begin{array}{l}-0.05 \\
(0.39)\end{array}$ \\
\hline Property portion of capital tax rate, actual & & & $\begin{array}{c}0.03 \\
(0.16)\end{array}$ & & $\begin{array}{l}-1.88 \\
(1.02)\end{array}$ \\
\hline adj- $R^{2}$ & .46 & .45 & .54 & -.04 & .04 \\
\hline
\end{tabular}
return

\begin{tabular}{|c|c|c|c|c|c|}
\hline independent variables $\quad$ dependent variable: & $\begin{array}{l}\text { paper } \\
\text { return }\end{array}$ & $\begin{array}{l}\text { paper } \\
\text { return }\end{array}$ & $\begin{array}{l}\text { paper } \\
\text { return }\end{array}$ & $\begin{array}{l}\text { stock } \\
\text { return }\end{array}$ & $\begin{array}{l}\text { stock } \\
\text { return }\end{array}$ \\
\hline $\ln (1$-capital tax rate), actual & $\begin{array}{c}0.24 \\
(0.04)\end{array}$ & & & & \\
\hline $\ln$ (1-capital tax rate), forecast & & $\begin{array}{c}0.25 \\
(0.04)\end{array}$ & & $\begin{array}{c}0.12 \\
(0.24)\end{array}$ & \\
\hline ln (1-capital tax rate), forecast residual & & $\begin{array}{c}0.19 \\
(0.11)\end{array}$ & & $\begin{array}{c}0.03 \\
(0.69)\end{array}$ & \\
\hline Pers. portion of capital tax rate, actual & & & $\begin{array}{l}-0.83 \\
(0.33)\end{array}$ & & $\begin{array}{l}-2.71 \\
(2.16)\end{array}$ \\
\hline Corp. portion of capital tax rate, actual & & & $\begin{array}{l}-0.41 \\
(0.06)\end{array}$ & & $\begin{array}{l}-0.05 \\
(0.39)\end{array}$ \\
\hline Property portion of capital tax rate, actual & & & $\begin{array}{c}0.03 \\
(0.16)\end{array}$ & & $\begin{array}{l}-1.88 \\
(1.02)\end{array}$ \\
\hline $\operatorname{adj}-R^{2}$ & .46 & .45 & .54 & -.04 & .04 \\
\hline
\end{tabular}

\begin{tabular}{|c|c|c|c|c|c|}
\hline $\begin{array}{l}\text { dependent variable: } \\
\text { independent variables }\end{array}$ & $\begin{array}{l}\text { paper } \\
\text { return }\end{array}$ & $\begin{array}{l}\text { paper } \\
\text { return }\end{array}$ & $\begin{array}{l}\text { paper } \\
\text { return }\end{array}$ & $\begin{array}{l}\text { stock } \\
\text { return }\end{array}$ & $\begin{array}{l}\text { stock } \\
\text { return }\end{array}$ \\
\hline $\ln$ (1-capital tax rate), actual & $\begin{array}{c}0.24 \\
(0.04)\end{array}$ & & & & \\
\hline $\ln (1$-capital tax rate), forecast & & $\begin{array}{c}0.25 \\
(0.04)\end{array}$ & & $\begin{array}{c}0.12 \\
(0.24)\end{array}$ & \\
\hline $\ln (1$-capital tax rate), forecast residual & & $\begin{array}{c}0.19 \\
(0.11)\end{array}$ & & $\begin{array}{c}0.03 \\
(0.69)\end{array}$ & \\
\hline Pers. portion of capital tax rate, actual & & & $\begin{array}{l}-0.83 \\
(0.33)\end{array}$ & & $\begin{array}{l}-2.71 \\
(2.16)\end{array}$ \\
\hline Corp. portion of capital tax rate, actual & & & $\begin{array}{l}-0.41 \\
(0.06)\end{array}$ & & $\begin{array}{l}-0.05 \\
(0.39)\end{array}$ \\
\hline Property portion of capital tax rate, actual & & & $\begin{array}{c}0.03 \\
(0.16)\end{array}$ & & $\begin{array}{l}-1.88 \\
(1.02)\end{array}$ \\
\hline adj- $R^{2}$ & .46 & .45 & .54 & -.04 & .04 \\
\hline
\end{tabular}

Notes: (1) A constant term is included in all specifications

(2) Variables used to forecast are the promised (as of the prior year) nominal yield on commercial paper, the gap between yields on BAA and AAA bonds, and lagged: consumption growth, stock return, $\ln$ (1-capital tax rate), unemployment rate, inflation, and $\ln ($ rental rate). Bond yields and inflation are excluded when the forecasts are to be used in the paper return equation.

\section{Summary and Conclusions}

A first examination of the time series shows no evidence of overshifting of the capital income tax. In other words, the pre-tax rental rate increases by no more than the amount of the capital income tax. Even if we discard the pre-1930 observations from Figure 3, the regression slope is still around one, and we suspect that the magnitude of the slope is overstated because of other sources of capital tax cyclicality (in terms of equation (1), a positive correlation between $\tau$ and $\varepsilon$ ). More research is needed to determine which of the "imperfect competition" models of capital accumulation and aggregate economic activity are consistent with my findings. 
Some of the longer term comparisons suggest that, although there is no overshifting, capital bears very little of the burden of capital income taxes. For example, there was a lot more capital taxation after World War II than 1900-29, but consumption growth, commercial paper returns, and stock returns were essentially the same during the two periods.

The annual post-war data show a significant negative correlation between pre-tax rental rates and, in some specifications, no correlation between consumption growth and tax rates. These findings are consistent with a lot of shifting, but they may only be the result the cyclical behavior of my tax measures. Controlling for an unemployment rate forecast, capital taxes seem to significantly reduce consumption growth without significantly raising rental rates. This suggests that there is little shifting, or perhaps that there is shifting which creates unemployment. Overall, one might characterize the time series as showing little shifting in the "short run" and a lot of shifting in the "long run," although more empirical work needs to be done regarding the measurement of key variables in a consistent way over long time periods, and separating the effect of the business cycle on capital tax rates from the effect of tax rates on the business cycle. More work also needs to be done with comparing these data with models of capital tax incidence.

\section{Appendix: Data Sources}

capital, current cost The current cost net stock of private fixed assets at the end of the previous year, as reported in BEA's Table 1.1 “Current Cost Net Stock of Fixed Assets and Consumer Durable Goods"(1926-99), and Kendrick's private domestic capital stock (1961, Table A-XV, 1900-25). The Kendrick series is merged with the BEA series by multiplying the former by 0.771 in order to make the levels of the two series identical in 1925. "Capital" as referenced in the text is current cost capital, unless noted otherwise.

capital income Real income to domestically employed private capital, calculated as $\left(Y-Y_{g}\right)\left[1-W_{p} /\left(N I-W_{g}-Y_{s}\right)\right]$, where $Y$ is real net domestic product, $Y_{g}$ is the real net product of the government sector, $Y_{s}$ is proprietors' income, $N I$ is national income, $W_{p}$ is the private employee compensation of domestic residents, and $W_{g}$ is the labor compensation of domestic government employees. Capital income after-tax is calculated by subtracting real capital tax revenue (deflated with the GDP deflator) in the corresponding tax year.

capital rental rate capital income/capital. The after-tax rental rate is real capital income after-tax 
per dollar of capital. "Capital" is measured at current cost, unless noted otherwise in the text.

capital tax revenue Federal, state, and local personal capital income, corporate income, property, excess profit, capital stock, and document \& stock transfer tax revenue. Federal personal income, corporate income, and excess profits tax revenues are dated by tax year as reported by IRS (various issues). State and local revenues are dated by the year in which they arrive in the state treasuries from U.S. Council of Economic Advisers (1996, 1999). Personal capital income tax revenue is calculated as the product of personal income tax revenue and one minus labor's share of AGI (191699). Before 1916, the latter is assumed to change proportionally with labor's share of national income.

capital tax rate Capital tax revenue/capital income. see also the formula in the text.

consumption Nominal expenditure from Kenrick (1961, Table A-IIb, 1899-1928) and BEA NIPA Table 1.01, line 2 (1929-99) plus $\$ 2$ b for alcohol (1929-32, \$1.335b for 1933). Since 1929, BEA decomposes consumption into expenditures on nondurables, durables, and services. Real expenditure per person aged 15+ calculated by dividing by the GDP implicit price deflator and Population aged 15+. In order to increase comparability with Hall (1988), I report results in the body of the paper derived from the nondurables-only consumption measure. Appendix I explores alternative specifications.

domestic product $\quad$ Gross from Kendrick(1961, Table A-III, 1900-28) and BEA NIPA Table 1.1, line 1 (1929-99). Net from Gross minus Kendrick's (1961, Table A-III, 1900-28) National Capital Consumption Allowances and directly from BEA NIPA Table 1.12, line 1 (1929-99). Net product of the government sector from Kendrick (1961, Table A-III, 1900-29) and BEA NIPA Table 1.12, line 10 (1929-99). Labor's share of nonproprietor's income from Kendrick (1961, Table 28, 190028, missing years linearly interpolated). Since 1929, employee compensation of domestic residents from BEA NIPA Table 1.15, line 53 and compensation of government employees from BEA NIPA Table 1.15, line 44. Proprietor's income from BEA NIPA Table 1.15, line 54.

GDP implicit price deflator Kendrick $(1961,1899-1928)$ and BEA NIPA Table 701, line 4 (1929-99).

investment price index The ratio of the NIPA investment and consumption deflators, as reported by BEA NIPA Table 701, lines 8 \& 24 (1929-99).

long-term bond yields $\quad$ Moody's AAA corporate bond yield as reported by Citibase series FYAAC (1919-99) and spliced with Census Bureau series HS X-490 by adding 50 basis points to 
the latter. Moody's AAA corporate bond yield is an annual average of monthly yields reported on by St. Louis Fed (1919-99).

national income, and components National income from BEA NIPA Table 1.14, line 1 (1929-) and Census Bureau HS F-7 (-1928). Employee compensation and proprietors' income with inventory valuation and capital consumption allowance from BEA NIPA Table 1.14, lines 2 and 9 (1929-). As shares of national income, employee compensation and proprietors' income are reported by Johnson (1954, Table 1) at 5 year intervals prior to 1929; I linearly interpolate in between years. population aged 15+ Calculated as the product of total population and the fraction of the population that is aged 15+. Both series are from the Census Bureau (1975, series HS A-29, 1899-1969 and April 2000 Internet Release, 1970-99), except that the fraction aged 15+ is not always measured directly, and in these cases interpolated between Census years.

real paper yield For year $t$, the nominal yield promised in year $t$ - 1 on 4-6 month prime commercial paper, as recorded by the Census Bureau (1975, series HS X-445, 1899-1969) and U.S. Council of Economic Advisers (1999, Table B-73), minus the GDP deflator log change from $t$ - 1 to $t$. 


\section{Summary Statistics, 1947-96}

\begin{tabular}{lllll} 
variable & mean & std dev & min & $\max$ \\
\hline pre-tax capital rental rate & 0.095 & 0.011 & 0.073 & 0.121 \\
capital tax rate, total & 0.388 & 0.053 & 0.279 & 0.495 \\
capital tax rate, personal portion & 0.072 & 0.009 & 0.052 & 0.093 \\
capital tax rate, corporate portion & 0.169 & 0.054 & 0.096 & 0.309 \\
capital tax rate, property portion & 0.147 & 0.019 & 0.112 & 0.199 \\
nondurable cons. growth & 0.007 & 0.017 & -0.035 & 0.041 \\
nondur \& serv. cons. gr. & 0.020 & 0.013 & -0.013 & 0.037 \\
real paper return & 0.017 & 0.031 & -0.094 & 0.087 \\
real stock return & 0.085 & 0.138 & -0.279 & 0.422 \\
nominal paper yield & 0.055 & 0.032 & 0.008 & 0.148 \\
unemployment rate & 0.057 & 0.016 & 0.029 & 0.097 \\
\hline
\end{tabular}

\section{References}

American Council for Capital Formation. "The Role of Federal Tax Policy and Regulatory Reform in Promoting Economic Recovery and Long-Term Growth” Congressional Testimony, November 28, 2001.

Auerbach, Alan J. "Corporate Taxation in the United States." Brookings Papers on Economic Activity. 2, 1983: 451-505.

Besley, Timothy J., and Harvey S. Rosen. "Sales Taxes and Prices: An Empirical Analysis." National Tax Journal. 52(2), June 1999: 157-78.

Bureau of Economic Analysis. "Fixed Assets and Consumer Durable Goods: Estimates for 192598.” Survey of Current Business. 80(4), April 2000. 17-30.

Cummins, Jason G., Kevin A. Hassett, and R. Glenn Hubbard. "A Reconsideration of Investment Behavior Using Tax Reforms as Natural Experiments." Brookings Papers on Economic Activity. 2, 1994: 1-59. 
Due, John F. "The Effect of the 1954 Reduction in Federal Excise Taxes on the List Prices of Electrical Appliances.” National Tax Journal. 7(3), September 1954: 222-6.

Evans, William N. Jeanne S. Ringel, and Diana Stech. "Tobacco Taxes and Public Policy to Discourage Smoking." Tax Policy and the Economy. 13, 1999: 1-55.

Feldstein, Martin S, Louis Dicks-Mireaux, and James Poterba. “The Effective Tax Rate and the Pretax Rate of Return.” Journal of Public Economics. 21(2), July 1983: 129-58.

Feldstein, Martin and Lawrence Summers. "Is the Rate of Profit Falling?" Brookings Papers on Economic Activity. 1, 1977: 211-27.

Feldstein, Martin S. and Lawrence Summers. "Inflation, Tax Rules, and the Long-Term Interest Rate.” Brookings Papers on Economic Activity. 1, 1978: 61-99.

Griliches, Zvi and Dale W. Jorgenson. "Sources of Measured Productivity Change: Capital Input." American Economic Review. 56(1), March 1966: 50-61.

Haig, Robert M. and Carl Shoup. The Sales Tax in the American States. New York: Columbia University Press, 1934.

Harberger, Arnold C. "The Incidence of the Corporation Income Tax." Journal of Political Economy. 70, 1962: 215-40.

Johnson, D. Gale. "The Functional Distribution of Income in the United States, 1850-1952." Review of Economics and Statistics. 36(2), May 1954: 175-82.

Kendrick, John W. Productivity Trends in the United States. Princeton: Princeton University Press, 1961.

Lucas, Robert E., Jr. "Supply-Side Economics: An Analytical Review.” Oxford Economic Papers. 42(2), April 1990: 293-316.

Mendoza, Enrique G. Assaf Razin and Linda L. Tesar. "Effective Tax Rates in Macroeconomics: Cross-Country Estimates of Tax Rates on Factor Incomes and Consumption.” Journal of Monetary Economics. 34(3), December 1994: 297-323.

Mitrusi, Andrew and James Poterba. "The Distribution of Payroll and Income Tax Burdens, 1979-99.” National Tax Journal. 53(3), Part 2 Sept. 2000: 765-94.

Mulligan, Casey B. "Capital, Interest, and Aggregate Intertemporal Substitution.” NBER Working paper, December 2002.

Mulligan, Casey B. and Justin G. Marion. "Average Marginal Tax Rates Revisited: Comment." Working paper, University of Chicago, August 2000. 
Parker, Robert P., et al. "Preview of the Comprehensive Revision of the National Income and Product Accounts: Recognition of Government Investment and Incorporation of a New Methodology for Calculating Depreciation.” Survey of Current Business. 75(9), September 1995: 33-41.

Poterba, James M. "Retail Price Reactions to Changes in State and Local Sales Taxes." National Tax Journal. 49, June 1996: 165-76.

Sidhu, Nancy D. "The Effects of Changes in Sales Tax Rates on Retail Prices." in Proceedings of the Sixth-Fourth Annual Conference on Taxation. 720-33. Columbus: National Tax Association - Tax Institute of America, 1971.

United States Council of Economic Advisers. Economic Report of the President. Washington, DC: Government Printing Office, various issues. 